결핵 및 호흡기질환 Vo1. 19, No. 1, Jan., 1972

\author{
의료보험과 국가결핵 관리 제: 도 \\ 결 협·결 핵 연 구 원 \\ 이 창 주

\section{Medical Insurance and National Tuberculosis Control System in Korea} \\ Chang Choo Lee, M.D.
}

Korean Institute of Tuberculosis, KNTA

\section{1. 서 론}

복지국가 건설은 우리의 공동 염원이나 사희적 경제 적 제약을 받는 개발 도상국가에서는 의료혜택의 평준 화조차도 이루어져 있지 못하고 있는 것은 사실이다. 그러나 우리의 공동염원 달성을 위한 노력은 꾸준히 계 속되어 왔으며 그 목적 달성 과정에서 우리의 현실이 허용하는 법위내에서 부분적으로 흑은 단계적으로 제 도상의 발전을 하고 있는 것도 사실이다. 즉 우리나라 에서의 공무원의 건강진단, 질병, 부상, 폐질, 분만, 퇴 직, 사망에 대한 사회보장을 목적으로 하는 공무원 연 금법, 업무수행 과정에서 발생하는 상병에 대한 보장으 로서 산업재해보험법, 돌발 사고로 인한 상해를 보장한 자동차 손해배상 보험법, 생활 무능력자에 대하여 국가 가 공여하는 의료보호 및 보건소망을 통한 무료진료 등 은 복지국가 건설을 향한 우리의 노력 과정에서 현실이 허용하는 범위내에서 실시되고 있는 부분적인 사회보장 제도들이라고 볼 수 있을 것이다.

그러나 우리나라에서 이러한 제도에 의한 수혜도는 전국민의 3-4\%에 불과하다고 한다. 보사부는 1966년 사회보장 심의위원희로 하여금 국민 의료보험 실시 가 능성을 연구케 하기위하여 의료보험 시범 사업을 몇몇 기업체(봉명광업소, 호남비료)에 실시하여 그 결과를 토대로 국민 의료 보험 장기 계획을 수립하고 연차적으 로 국민의 의료보험 수혜율을 증가시켜 1986년에는 전 국민의 $88.9 \%$ 를 보장 할 수 있을 것이라고 한다.

결핵은 전체상병의 견지에서 볼 때 한 질병에 지나지 않지만 그 만연도가 높고 국민 보건, 국가노동력에 끼 치는 손실이 크며 그 치료 기간도 장기간 소요되므로
중대한 질환이나 또 그 치료와 예방법은 거의 완성되어 있어서 다만 국가적 대규모 실천방안의 가부에 따라서 이병을 쉅게 극복할수도 있고 그렇지 못 할수도 있다는 것을 우리들은 역사적으로 잘 알고 있다. 그러므로 우 선적으로 결핵병을 보험의 대상으로 해서 그 치료와 예 방에 있어서 우리나라도 선진국과 같이 신속하고 막대한 효과를 얻을 수가 있도록 해야할 필요성이 있다고 생각 된다.

그런데 현재 보건사회부가 계흭한 의료보험에는 이질 환이 장기간 치료를 요하는 치료비 부담이 불가능하다 는 이유때문에 결핵이 제외되어 있다.

저자는 이러한 생각은 큰 착각에서 기인한 것이라고 믿으며 여기에 다음과 같이 결핵치료의 비용을 추산해 보고 결핵을 의료보험에 가입시킬 수 있는 가능성을 검 토하고, 그 제도에 대한 연구를 시도해 보았다.

\section{2. 사회보장이념 및 현실에 대한 고찰}

\section{2-1. 우리나라의 사회보장의 현실}

우리나라의 사회보장 제도의 현실에 대하여서는 서론 에 언급한 바 있다. 앞으로 있어야 할 사회보장 제도로 서는 전체국민의 건강보장, 실업보장, 노년보장, 아동 복지 보장, 신체장애자 복지보장, 정신박약자 복지보장 등이 있다.

\section{2-2. 선진국가의 사회보장 현실}

자유 민주주의 정치 이념에 입각한 선진국가들의 사 회 보장에는 국민의 최저 생활을 보장하고 있으며, 완 전 고용정책을 수립하여 빈곤의 원인인 실업을 규제하 고 나아가 교육 문화생활 환경 등에 관한 전국민의 복 지를 보장하고 있다. 현재 소위 자유진영국가들 중에서 
발딜된 국가로 인정받는 나라는 스웨덴, 노르웨이, 덴 마크, 핀란드, 영국을 들 수 있다고 하며, 다음으로 잘 된나라 서독, 불란서, 일본, 이태리, 호주, 뉴질랜드 등이다. 이들 나라에서는 국민의 질병, 노동재해 사망, 폐질, 임신, 분만, 보육, 가족부양, 미망인, 고아, 소 득감소 또는 상실로 오는 생존의 위협, 사회생활상의 사고 등에 대하여 국가 보장 제도가 되어있다.

\section{2-3. 사회보장 제도의 이념}

사회보장제도라는 것은 누구 누구를 위해서 하는것이 아니라 전국민이 다 한 겨레라고 인정하고 또 각자가 자기의 사회적 책임을 완수하는데 있어서 이것이 가능 한 수 있도록 환경조성을 하는데 필요한 상호의 협력을 국가적으로 발전시킨 것이며 노력과 협동 정신의 발휘 없이는 이루어 질 수 없는 것이다. 그러나 이러한 일이 시초에는 의례히 기업주와 근로자 혹은 정부와의 사이 에 마찰이 있기 마련이고 또 이사회 보장제도의 규모와 포함범위의 결정을 하는데 있어서는 여러가지 의견의 차이가 있을수 있을 것이다.

또 이 제도를 실천하는데 있어서도 정부가 전담하느 냐 혹은 일부를 사기업체인 보험회사나 협동조합등에 위임하느냐 하는 것은 각국가의 정치이념에 따라서 다 를 것이다.

\section{2-4. 결핵, 심장보험}

싱가폴 공화국의 결핵심장 보험은 특이한 예로서 들 수 있다. 싱가폴 공획국의 일반 의료보험 제도는 알수 없으나 영국식 행정을 따르고 있는 이나라에서의 의료 제도는 보혐이 없다 하더라도 국가가 운영하는 병원에 서 무로 치료를 받을수 있는 제도가 결핵에 한하여서는 확립되어 있다.

선진국에 비해 손색없는 치료가 실시되고 있고, 일차 약, 이차약을 필요에 따라 거의 제한없이 사용하며, 입 원, 수술이 필요하면 무료로 시행된다. 이런 견지에서 보면, 견핵보험의 필요성은 없는 것으로 생각되기도 했 다. 그러나 실제로는, 1968년 말 현재로 인구 약 2, 000, 000 의 싱가폴 공화국에서 48,042 명의 보험가입자가 있 으며 이 숫자는 우리나라의 인구를 $30,000,000$ 으로 생 각했을 경우의 720,630 명에 해 당하는 것이다.

상기 싱가폴의 보험 가입자 중에서 새로히 환자로 발 견된자는 110 명이였고 이들 환자는 도합 1,160 일의 병 가를 허용받았으며 이는 일인 평균으로 따져보면 10.5 일(연간)의 병가밖에 안되머 견핵치로 환자로서는 의외 로 짧은 병가라고 하겠다.

여기서는 근로기준법의 강력한 뒷받침이 있어서 근로 자의 병가시는 고용주가 월급을 지불해야 하는 의무가
있는데 결핵환자가 보험에 가입하므로서 평균 병가일이 단축되어 기업주에게 이익이 돌아가는 것이다.

우리나라에는 보험으로 받는 이익에 대해서 환자나 기업주의 인식이 부족한데다 근로기준법의 뒷받침도 약 한것이 사실이지만 이런 특이한 결핵심장보험(단일질환 에 대한 보장 보험)은 전체적인 일반 의료 보험이 불가 능한 시점에 있는 개발도상국가가 채택 가능성을 검토 해 볼 가치가 있는 것으로 생각된다.

\section{3. 결핵보헙제도 계획 수립의 참고자료}

\section{3-1. 항결핵제}

일차약으로서는 Nydrazid(INH), paraamino-salicylicacid(PAS) Streptomycin(SM)이 있으며, 이차약제 로서는, prothionamide(1321), Ethambutol(EMB), Pyrazinamide(PZA), Kanamycin(KM), Cycloserine (CS), Capreomycin(CM), Rifampicin(RF) 등이 있다. 치료의 원칙은 삼자병합을 원칙으로하고 초치료에는 일 차약을 사용하고, 일차약 내성획득시에 이차약을 사용 한다. 여기에서는 최소 치료기간을 18 개월로 했다.

\section{3-2・ 항결핵제 가격표}

항결핵제 가격은 현재 서울시내 모 결핵전문 진료소 (비영리기관)에서 실시하고 있는 수가를 기준으로 하여 비용의 추리를 하였다. 다음표는 그 진료소의 수가 규 정표이다.

\begin{tabular}{|c|c|c|c|}
\hline 명 & 수 량 & $\mathrm{mg}$ & 수 \\
\hline PAS & 1 정 & $0.5 \mathrm{gm}$ & 1원 \\
\hline SM & 1 병 & $1 \mathrm{gm}$ & $50 \prime \prime$ \\
\hline INH & 1 정 & $100 \mathrm{mg}$ & $2 \prime \prime$ \\
\hline 1321 & 1 정 & $125 \mathrm{mg}$ & $30 "$ \\
\hline ETB & 1 정 & $250 \mathrm{mg}$ & $40 " /$ \\
\hline $\mathrm{PZA}$ & 1 정 & $250 \mathrm{mg}$ & $20 " \prime$ \\
\hline $\mathrm{KM}$ & 1 병 & $1 \mathrm{gm}$ & $500 /$ \\
\hline $\mathrm{CS}$ & 1 갑 & $250 \mathrm{mg}$ & $70 " \prime$ \\
\hline $\mathrm{RF}$ & 1 갑 & & $330 /$ \\
\hline
\end{tabular}

\section{3-3. 보험시범 사업소 년도별 현황}

다음포는 보사부 의료보험 시범사업소로 설정된 봉명 광업소와 호남비료의 연도별 피보험자의 현황이다. 
결핵 및 호홉기질환 Vol. 19, No.1, Jan., 1972

표 2. 연도별 피보험자 현항

\begin{tabular}{|c|c|c|c|c|}
\hline \multirow{3}{*}{ 조 } & & 년 & & 도 \\
\hline & & 1966 & 1967 & 1968 \\
\hline & & $\begin{array}{l}\text { 피보험|부 } \\
\text { 자 수가족 }\end{array}$ & 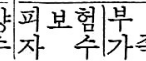 & 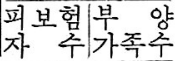 \\
\hline
\end{tabular}

\begin{tabular}{rr|r|r|r|r|r|r}
\hline 호 & 남 & 655 & 2,036 & 719 & 2,781 & 660 & 2,607 \\
봉 & 명 & 625 & 2,642 & 640 & 2,792 & 580 & 2,565 \\
\hline 계 & & 1,190 & 4,678 & 1,359 & 5,573 & 1,240 & 5,171 \\
\hline
\end{tabular}

3-4. 의료비

다음표는 봉명 광업소, 호남비료의 보험사업의 의료비 지출실태를 연도별 조합별로 표시한 것이다.

표 3. 연도별 조합별 의료비(단위 1,000 )

\begin{tabular}{|c|c|c|c|c|c|c|c|c|c|}
\hline \multirow[b]{3}{*}{ 의료바 } & \multicolumn{6}{|c|}{ 년 } & \multicolumn{3}{|c|}{ 도 } \\
\hline & \multicolumn{3}{|c|}{1966} & \multicolumn{3}{|c|}{1967} & \multicolumn{3}{|c|}{1968} \\
\hline & 호남 & 봉명 & 평 균! & 호남 & 봉명 & 평 균| & 호남 & 봉명 & 평 균 \\
\hline 조 합 부 담 & 335 & 175 & 250 & 439 & 538 & 398 & 678 & 474 & 576 \\
\hline 환 자 부 담 & 118 & 82 & 100 & 183 & 166 & 175 & 275 & 209 & 242 \\
\hline 계 & 453 & 257 & 350 & 620 & 524 & 572 & 953 & 683 & 818 \\
\hline 의 료비 증가율 & & & 100 & 137 & 204 & 164 & 210 & 268 & 234 \\
\hline 수지실적비 교 & + & + & & + & + & & + & - & \\
\hline 과 부 족 & 374 & 647 & & 842 & 221 & & 143 & 120 & \\
\hline
\end{tabular}

3-5. 보험수혜자(피보험자와 가족) 10,000 명단 치료비

표 4. 보험수혜자 10,000 당 치료비(단위 1,000 )

\begin{tabular}{|c|c|c|c|c|c|c|}
\hline \multirow{3}{*}{$\begin{array}{l}\text { 치 료 비 } \\
\text { 부 담 별 }\end{array}$} & \multicolumn{4}{|c|}{ 년 } & \multicolumn{2}{|l|}{ 도 } \\
\hline & \multicolumn{2}{|c|}{66} & \multicolumn{2}{|c|}{67} & \multicolumn{2}{|c|}{68} \\
\hline & 호남 & 봉명 & 호남 & 봉명 & 호남 & 봉명 \\
\hline 조합부담 & 1,288 & 536 & 1,249 & 1,043 & 2,075 & 1,507 \\
\hline 환자부담 & 454 & 251 & 523 & 484 & 842 & 665 \\
\hline 계 & 1,742 & 787 & 1,771 & 1,527 & 2,917 & 2,172 \\
\hline $\begin{array}{l}\text { 수지실적 } \\
\text { 비 교 }\end{array}$ & & + & & + & + & - \\
\hline 과 부 족 & 1,437 & 1,980 & 2,405 & 643 & 437 & 381 \\
\hline
\end{tabular}

상기표는 II-4를 보험수혜자수를 10,000 으로 하고 환 산된 치료비이다.

\section{3-6. 경핵 유병율}

1970년도에 실시한 전국결핵 실태조사 보고(대한결핵 협회)에 의하면 5 세 이상의 인구에서는 100 명중 4.2 명 이 엑스선상의 활동성 결핵 환자이고, 1,000 당 7.6 명은 세균학적으로 균이 증명된 개방성 환자인 것으로 밝혀 졌다. (다음표 참조)

표 5. 결 핵 유 병 율

\begin{tabular}{lll|c|c}
\hline 년 & 도 & 엑스선상의 유병율 & 세 균학적인 유병율 \\
\hline 1976 & 4.2 & 0.76 \\
196 & 5 & 5.1 & 0.93
\end{tabular}

유병율 상으로 추산하면 인구 10,000 명중의 결핵환자 는 420명이 된다. 보험에서 혜택을 받을수 있는 환자는 보험 가입(창설당시) 당시에 환자는 제외되는 것이 원 칙이어야 하기 때문에 여기에서는 제의되어야 한다.

\section{3-7. 년간 결핵환자 발생율}

표 6. 연간 결핵환자 발생율

\begin{tabular}{|c|c|c|c|c|}
\hline \multirow{2}{*}{\multicolumn{2}{|c|}{ 나 라 별 }} & \multicolumn{3}{|c|}{ 연간 결핵환자 발생율 } \\
\hline & & 기 & $\begin{array}{l}\text { 엑스선상의 } \\
\text { 발 생 율 }\end{array}$ & $\begin{array}{l}\text { 세 균학적인 } \\
\text { 환자발생 율 }\end{array}$ \\
\hline 한 & 국 & $1969-1970$ & 0.60 & 0.33 \\
\hline 한 & 국 & $1970-1971$ & 0.35 & 0.24 \\
\hline 일 & 본 & $1953-54$ & 0.37 & \\
\hline 일 & 본 & $1963-64$ & 0.17 & 0.01 \\
\hline
\end{tabular}

상기표는 1971년 11월 27 일 부산에서 개최된 제 33 차 결핵학술대회에서 발표된 것으로 1970-1971년 결핵환 자 발생 실태조사 결과를 예비 발표한 것으로 차후 약간 의 수정이 있을수 있다는 전제하에 발표되있다.

이에 의하면 세균학적인 발생율과 엑스선상의 발생율 의 비가 일본에서는 $1: 17$ 인데 비해, 한국에서는 $24: 35$ 약 $1: 1.45$ 로 큰 격차가 있어 한국의 엑스선상의 발생율 약 간 높은 쪽으로 정하고 이를 기준으로 하였다. 19691970년 사이의 발생율은 $0.60 \%$ 인 것은 조사대상이 통계 학적으로 전국의 대표가 될 수 없어서 임의로 이 보다는 약간 낮은 그러나 $0.35 \%$ 보다는 높은 $0.5 \%$ 를 기준했다.

3-8. 조합원 10,000 명단 연간신환 발생 추산

연간 결핵환자의 발생수는 $0.5 \%$ 의 발생율을 적응시 키면,

$$
10,000 \times 0.5 \times \frac{1}{100}=50 \text { 명 }
$$


즉 10,000 명의 보험수혜인원 중에서는 연간 약 50 명 의 결핵환자가 발생할 것으로 추산할 수 있다.

\section{3-9. 약품비}

약품비 추산은 현재 서울 모 결핵전문 진료소(비영리 기관)의 수가 규정을 참고하였다. (표 3-2 참조)

$$
\begin{array}{rrc}
\text { 아이나 } & 100 \mathrm{mg} & 1 \text { 정 }=2 \text { 원 } \\
\text { 아이나 } & 1 \text { 일 } & \text { 소요량 }=4 \text { 정 } \\
\text { 아이나 } & \text { 월 } & \text { 소요량 }=4 \text { 정 } \times 30 \text { 일 } \\
\text { 아이나 } & \text { 연간 } & \text { 소요량 }=4 \text { 정 } \times 30 \times 12
\end{array}
$$

환자 1 인당 아이나 연간 약품비 $=2$ 원 $\times 4 \times 30 \times 12=$ 2,880 원

$$
\begin{array}{rrl}
\text { 파-스 } & 0.5 \mathrm{~g} & \multicolumn{2}{c}{1 \text { 정 }=1 \text { 원 }} \\
\text { " } & 1 \text { 일 } & \text { 소요량 }=20 \text { 정 } \\
\text { " } & \text { 월 } & \text { 소요량 } \quad 20 \text { 정 } \times 30 \\
\text { " } & \text { 연간 } & \text { 소요량 } \quad 20 \text { 정 } \times 30 \times 12
\end{array}
$$

환자 1 인당 파스 연간 약품비 1 원 $\times 20 \times 30 \times 12=$ 7,200 원

$$
\begin{array}{cccc}
\text { S. M } & 1 \mathrm{gm} & 1 \text { 병 } & 50 \text { 원 } \\
\text { " } & 1 \text { 일 } & \text { 소요량 } & 1 \text { 병 } \\
\text { " } & \text { 월 소요량 } & 1 \times 30 \\
\text { " } & \text { 초 } 3 \text { 개월간 소요량 } 1 \times 30 \times 3 \\
\text { " } & \text { 9개 월간 소요량 } 1 \times 2 \times 34 \text { 주 }
\end{array}
$$

연간소요량 $1 \times 30 \times 3+1 \times 2 \times 34$

연 간약가 $\quad 50 \times 30 \times 3+50 \times 2 \times 34=7,900$ 원

1 인 당 $\mathrm{INH}+\mathrm{PAS}+\mathrm{S} . \mathrm{M}$ 연간약값 2,880 원 +7, 200원 + 7,900 원 $=17,980$ 원

3-10. 제검사비

$$
\begin{aligned}
& \text { 엑스레,이 } 1 \text { 회 } 800 \text { 원 년 } 4 \text { 회 } 3,200 \text { 원 } \\
& \text { 도 말 1회 50원 년 2회 } 100 \text { ” } \\
& \text { 배 약 1회 100원 년 2회 } 200 \text { " } \\
& \text { 계 } 3,500 \text { ” }
\end{aligned}
$$

\begin{tabular}{|c|c|c|c|c|c|}
\hline $\begin{array}{l}\text { 업체수및 } \\
\text { 근로자수 }\end{array}$ & & 단 & 위 & $\bar{T}$ & \\
\hline & $50-499$ & $500-999$ & $\begin{array}{r}1,000- \\
1,999\end{array}$ & $\begin{array}{c}2,000 \\
\text { 이 상 }\end{array}$ & 계 \\
\hline 기업체수 & 3,896 & 122 & 42 & 15 & 4,075 \\
\hline 근로자수 & 437,222 & 84,128 & 57,593 & 43,906 & 622,849 \\
\hline 백 분 률 & 70.2 & 13.5 & 9.3 & 7.0 & 100.0 \\
\hline
\end{tabular}

3-11. 환자 일명당 제비용

$\begin{array}{cr}\text { 약품비 } & 17,930 \text { 원 } \\ \text { 재검사비 } & 3,500 \text { 원 } \\ \text { 계 } & 21,480 \text { 원 }\end{array}$

\begin{tabular}{|c|c|c|c|c|c|}
\hline 년 & 도 & & & 보 험 자 & 부 양 가 족 \\
\hline \multirow{2}{*}{66} & 호 & 남 & & 655 & 2,036 \\
\hline & 봉 & 명 & & 625 & 2,642 \\
\hline \multirow{2}{*}{67} & 호 & 남 & & 719 & 2,781 \\
\hline & 봉 & 명 & & 640 & 2,792 \\
\hline \multirow{2}{*}{68} & 호 & 남 & & 660 & 2,607 \\
\hline & 봉 & 명 & & 580 & 2,565 \\
\hline & & 계 & & 3,789 & 15,422 \\
\hline
\end{tabular}

3-12. 보험 수혜자 10,000 명중의 환자치료 총비용 3-8에 의하여 50 명 환자를 예 상하므로

21,480 원 $\times 50=1,074,000$

3-13. 기업체 근로자 인원 현황(1968년도 현재) ※ 표 7 참조

3-14. 근로자와 가족비율 ※ 표 8참조

3-15. 근로자 전체 가족의 추산(1968년말 현재) 3-14에서 근로자 : 부양가족 $=1: 4$
결핵 및 호흡기질환 Vol. 19, No. 1, Jan., 1972

전근로자수 $622,894 \times 4=2,491,396$ 명 으로 추산된다. 고로 보험수혜 전체인원은=근로자十가족

즉 $622,849+2,491,396=3,114,245$ 명 으로 추산된다.

표 7. 기업체 근로자 인원현황(1968년도 현재)

표 8. 근로자와 가족비율

근로자 : 부양가족 $=1: 4$ (약)

\section{3-16. 근로자의 월평균 월급}

보사부에 의하면 1968년도 조사에서 근로자의 월평균 수입은 11,000 원으로 추산하고 있다. 그동안의 월급의 인상을 고려하여 여기 보험료 추산에서는 근로자의 평 균 월급을 15,000 원으로 정하고 추산하였다.

3-17. 전근로자(가족포함) 결핵보험 소요예산 추산 (1968년말 현재 기준)

3-12와 3-15에서

$$
1,074,000 \times \frac{3,114,245}{10,000} \fallingdotseq 334,471,911
$$

약 3 역 3 천 4 백만원이 약품과 재검사에 소요될것으로 추산된다.

3-18. 적정선의 보험율 추산

3-16에서 언급한 바 있지만 여기서는 근로자의 월평 균 월급을 15,000 원으로 기준하고 추산하였다.

3-17에서 전체 소요 금액은 $334,471,911$ 원이며 전체 근로자수는 622,849 (1968년 말 현재)이다.

고로 전체소요금액의 전 근로자의 월급액 전체의 백분 율은 


\section{$\frac{334,471,911}{15,000 \times 622,849 \times 12} \fallingdotseq 0.0029$ 로서 월급의 약}

$0.29 \%$ 에 해당된다.

기업주와 분담하는 경우는 약 $0.19 \%$ 로 금액으로 따 지면 월평균 일인당 약 28 원이 된다.

이상의 비용이 보험을 시작하게 될 경우에 일차년도 에 소요되리라고 생각된 금액이다. 이차년도에는 약간 의 예상이 달라지게 된다.

\section{3-19 일차약 실패자의 추산}

일차약(INH, PAS, SM) 의 실패자의 추산은 힘든 다. 그러나 대체적인 추산은 불가능한 것은 아닐지 모 른다. (큰 오차를 인정한다면)

선진국의 보고로는 일차약만으로도 균양성자를 $90 \%$ 음전시킬 수 있다고 한다.

대체적으로 보험에 가입한자중에서 발생하는 환자 치 료의 성공율은 이를 상희하리라고 추산할 수 있을 것 이다.

그 이유로서는 두가지를 들 수 있을 것이다.

일반에서의 통계는 환자들이 이미 결핵의 중상을 가 진자들로서 진단되어 치료를 받은 결과에서 얻어진 것 이며 양성자에서 균음전된 것을 기준한 것이지만, 보 험 가입자 중에서 발견되는 환자는 매년 집 단검진에서 이상의 가까운 상태에서 조기 발견되는 환자들이기 때 문에 개방성 환자의 수도 극히 소수일 것으로 예측되기 때문이다. 그 이유는 보험 창립시에는 신체검사가 필요 하며 이때의 결핵환자는 제외되어야 하기 때문이다. 이 런 견지에 과학적이라고는 할 수 없어도 일차년도의 치 료 성공율을 $95 \%$ 로 보고 실패자는 $5 \%$ 로 하고 추산하 였다.

그리고 이차약도 가장 보편적으로 사용되는 1321 , $\mathrm{EMB}, \mathrm{PZA}$, 삼자에 국한 시켰고 $\mathrm{RF}$ 과 같은 고가 약품 에 대해서는 제외하였다.

그리고, 실현가능성이 희박한, 제검사, (내성, 단층 촬영등, ) 및 입원, 수술은 고려하지 않았다.

3-20 약 품 비

$\begin{array}{crrl}1321 & 250 \mathrm{mg} & 1 \text { 정 } & 30 \text { 원 } \\ \text { " } & 1 \text { 일 } & \text { 소요량 } & 4 \text { 정 } \\ \text { " } & \text { 월 } & \text { 소요량 } & 4 \text { 정 } \times 30 \\ \text { " } & \text { 년간 } & \text { 소요량 } & 4 \text { 정 } \times 30 \times 12\end{array}$

가) 환자 1 인당 1321 년간약값 $30 \times 4 \times 30 \times 12=43,200$

$\begin{array}{cccl}\text { EMB } & 250 \mathrm{mg} & \text { 1정 } & 40 \text { 원 } \\ \text { " } & \text { 1일 } & \text { 소요량 } & 4 \text { 정 } \\ \text { " } & \text { 월 } & \text { " } & 4 \text { 정 } \times 30 \\ \text { " } & \text { 년간 } & \text { " } & 4 \text { 정 } \times 30 \times 12\end{array}$

나) 환자 1 인당 $\mathrm{EMB}$ 년간약값 $40 \times 4 \times 30 \times 12$

\begin{tabular}{ccll}
\multicolumn{2}{c}{57,600} & & \\
$\mathrm{PZA}$ & $250 \mathrm{mg}$ & 1 정 & 20 원 \\
" & 1일 & 소요량 & 4 정 \\
" & 월 & " & 4 정 $\times 30$ \\
" & 년간 & " & 4 정 $\times 30 \times 12$
\end{tabular}

다) 환자 일인당 $\mathrm{PZA}$ 연간 약값

20 원 $\times 4 \times 30 \times 12=28,800$

라) 환자일인당 $1321, \mathrm{EMB}, \mathrm{PZA}$, 삼자병합치료 년간 약값 $=43,200+57,600+28,800=129,600$

마) 보험수혜인원 10,000 중의 치료 실패자 추산

50 명 $\times \frac{5}{100}$ 실 패 율 $=2.5$ 명

바) 보혐수혜인원 10,000 중의 일차야 치료 실패로 이 차약 사용약가의 추산 $129,600 \times 2.5=324,000$ 원 2 차약은 일차년도에는 불필요한것을 원칙으로 했 다.

3-21 전체보험수혜자 (근로자와 가족)에 대한 이차약의

약값추산 (1968년 말 현재 기준)

가) 치료 실패자 추산

$50 \times \frac{3,114,245}{10,000} \times \frac{5}{100} \fallingdotseq 778$ 으로 약778명이다.

나) 약값 $=129,600 \times 778=100,812,800$

다) 실패자의 재검사비 $3,500 \times 778=2,723,000$

\section{3-22 이차년도의 약품비}

이차년도의 약품비용은 가) $5 \%$ 의 신환자와 나) 일차 년도에서 이월해오는 환자와, 다) 이월환자중의 일차약 실패자 이차약 사용비용으로서 구성된다.

가) $5 \%$ 의 신환의 비용은 일차년도와 동일하다.

\section{$334,471,911$ 원}

ㄴ) 이월환자

결핵의 치료는 2 년전후 필요하지만 여기서는 평균 1 년 6개월을 기준으로 했다. 이렇게 되면 이들 이월환자 에게는 아이나 파스의 유지량을 투여할 필요가 생긴다.

환자 1 인당 아이나, 파一스의 연간 치료는 각각 2,880 원 7,200 원 이므로(3-9참조)

아이나+파스의 6 개월간의 치료는 $\frac{2,880}{2}+\frac{7,200}{2}$

$=5,040$ 원 전체보험수혜자 아이나+파스 유지치 료비는 $5,040 \times \frac{50}{10,000} \times 3,114,245=78,478,974$

다) 이월 환자 재검사비

$$
1,750 \times \frac{50}{10,000} \times 3,114,245=27,249,643
$$

3-23 이차년도의 전체 비용은

$334,471,911+78,478,974+27,249,643+$ $+60,710,000=500,909,394$ 


\section{3-24 이차년도 근로자 보험율의 추산 (1968년도 말 기준)}

보험 수혜자 추산수 $3,114,245$ 명에 소요되는 전체비 용 $543,736,327$ 원 은 근로자 622,849 명의 평균 월급을 15,000 으로 하였을 때의 약 $0.48 \%$ 에 해당하며 기업주 와 근로자가 분담할 경우 약 $0.24 \%$ 로서 금액으로 따져 약 36 원이 된다.

\section{4. 우리나라의 결핵관리 현항과 제도}

현재 우리나라의 결핵치료는 국가가 전적으로 보장한 형식으로 무료 진단과 치료가 전국 192 개소의 보건소 망을 통하여 실시되고 있다.

치료의 질에 있어서는 국가의 경제적 여건의 취약성 때문에 INH, PAS, SM, 등의 일차약에 국한되어 있 으며, 2 차약을 자유롭게 사용하는 선진국이나 싱가폴 에 비하면 너무도 큰 차이를 보여주고 있다.

또한 전국에 산재하고 있는 종합병원, 시, 도립병원, 개업의 등에서도 결핵환자를 치료하고 있지만 치료비에 대한 보장이 없어서 경제능력이 있는 환자는 계속 치료 를 받을 수 있겠지만, 경제능력이 없는 자에게는 양질 의 치료 보장 제도는 없다. 그리고 현재 정부의 재정 형편으로서는 싱가폴 등지에서 시행되고 있는 국가부담 의 2 차약 사용은 그 전망이 요원하다고 생각된다.

이런 견지에서 어떤 조직체에 근무하는 근로자들은 기 업주의 협조를 받아 자신들의 건강을 자신들이 연대적 으로 책임을 지는 보험제도의 창설은 일정한 율의 보험 료 부담이 최저 생활의 위협이 되지 않을 경우에는 가 능할 것이라고 말할 수 있으며, 현재의 무보장 상태의 불우한 현실 극복의 실마리가 될 수 있을 것이다.

\section{4-1 보험제도하의 의료공급기관}

보건사회부는 의료보험법 시행령을 초안하여 1971년 도 하반기에 법제처에 회부하였으나 의료기관 지정문제 에 대한 의협의 항의에 부딛쳐 다시 재고 하도록 보사 부로 반송된 사실이 있다. 의협측은 환자에게 의료기관 선택의 자유를 부여하라고 주장하고 있다. 현재 대부 분의 국가에서 실시되고 있는 의료보험 제도는 의료기 관 선택은 환자의 자유에 속한다. 환자는 개업의를 포 함하여 어디서든지 치료를 받을 수 있다.

\section{4-2. 결핵전문의로 구성된 지역별 심의 위원회}

어뗘한 경-우에서도 질병에 대한 일정한 진단기준과 치료 읜칙이 있지만 특히 결핵보협에 있이시는 이의 필 요설이 더 많은 것이다.

상기 포는 1969년 결핵 및 호홤기질환 7월호 $\mathrm{Vol} 16$ $\mathrm{No3}$ 에 발포된 것이다. 다음의 포에 의하면 보건소에서
결핵 및 호홉기질환 Vo1. 19, No. 1, Jan., 1972

경중으로 진단한 597 명의 환자중 조사자(결핵전문의)는 371 명은 결핵으로 진단되어 보건소 진단과 일치 하였으 나 정상이 146 명 비횔동성 및 진단보류 56 명, 비결핵증 56 명으로 진단 불일치는 계 218 명으로 $30 \%$ 가 상회하는 불일치를 보이고 있다.

표 8. 진단의 차이

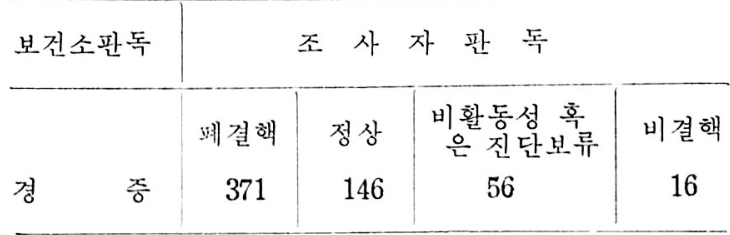

보험제도 하에서도 이런 결과가 나올 수 있다고 가정 할 때, 불필요한 환자의 치료로서 보험기금의 낭비를 예상 할 수 있다.

현재 일본에서도 지역별로 결핵심의 위원회가 조직되 어 있어, 개업의가 결핵 환자를 치료하려면, 일 단 엑스 선 사진 과거력, 치료 방향을 결핵 심의 위원회에 제출 하고 인정된 경우에 환자치료를 시작하고 치료비를 신 청 할 수 있는 제도가 되어 있다.

우리나라에서도, 이런제도는 모방할 가치가 있다고 보며, 지역별로 결핵전문의, 방사선 전문의, 우수한 개 업의로서 결핵심의 위원회를 조직하고 사전 승인 후에 치료에 임하는 것이 낭비를 방지하는 결과가 될 것이 다.

\section{5. 기타 참고 재료}

가) 일본의 결핵치료비 지불실태

표 9. 결핵 실태조사에서 발견된 환자의 의료비 지불 방법.

\begin{tabular}{|c|c|c|c|c|}
\hline 수 & 총 수 & 입원중 & $\begin{array}{l}\text { 재가 } \\
\text { 치료중 }\end{array}$ & $\begin{array}{l}\text { 취업 } \\
\text { 치 료중 }\end{array}$ \\
\hline${ }_{(\%)}$ 송 & $\begin{array}{r}468 \\
100.0\end{array}$ & $\begin{array}{r}84 \\
100.0\end{array}$ & $\begin{array}{r}150 \\
100.0\end{array}$ & $\begin{array}{r}234 \\
100.0\end{array}$ \\
\hline 피용자보험 본인 & 25.2 & 22.6 & 12.7 & 34.2 \\
\hline 피용자보험 가족 & 19.2 & 10.7 & 23.3 & 19.7 \\
\hline 국 & 41.9 & 39.3 & 48.7 & 38.5 \\
\hline $\begin{array}{l}\text { 피 용 자 보 험 } \\
\text { 가 족十생 보 }\end{array}$ & 0.4 & - & 0.7 & 0.4 \\
\hline 생 활 보 호 & 4.7 & 1.2 & 10.0 & 2. 6 \\
\hline 전 액 자 비 & 1.5 & 1.2 & 1.3 & 1.7 \\
\hline 기 & 7.1 & 25.0 & 3.3 & 3.0 \\
\hline
\end{tabular}


일본의 결핵환자는 거의 전원이 여러가지 형태의 보 험 흑은 기타 방법으로 보장된 치료를 받고 있음을 알 수 있다. 자비치료를 받는 자는 입원환자, 재가치료, 취업치료중에서 각각 $1.2 \%, 1.3 \%, 1.7 \%$ 를 점할뿐 대 다수가 여러가지 방법으로 보장되고 있음을 알수 있다.

우리나라에서는 보장된 치료는 보긴소 뿐이며, 그 나 마 일차약과 재가치료에 국한 되어 있다. 일본은 필요 에 따라 재가, 입원, 수술이 가능하고 일차약, 2 차약도 필요에 따라 자유롭게 사용 할 수 있는 현실과 비교하 면 너무도 뒤진 감을 면할 수 없다.

\section{6. 종합적 고찰}

여러 각도에서 결핵보험 가능성에 대하여 생각해 빘 다.

첫째 제도면에서, 보건소를 통한 무료 치료사업을 확 장해가는 것은 국가의 부담이 일방적으로 커갈 뿐이 며, 질의 향상의 속도는 지지 부진할 것으로 생각된다

바람직한 제도는 환자의 생활의 위협을 주지 않는 한 도에서 긴강할 때, 서로 연대적으로 책임을져서 일정 한 금액을 월급에서 떼어내어 저축하고, 환자가 되었을 때에 치료비 문제로 생활의 위협을 느끼지 않고 이상에 가까운 수준에서 치료를 받고 건강을 회복할 수 있는 제도의 창설이 필요하다. 이런 제도를 완성 시킬 수 있 는 전제 조건으로서, 완전고용이 요구된다.

완전 고용은 실제에 있어서 불가능할 것이므로 무직 자에게는 국가가 보장할 수밖에 없을 것이지만 현재의 보건소의 수준보다는 나은 치료가 배풀어져야 할것이며 현재 보건소에서 하고 있는 무차별한 무료제도를 지양 하고 이 무직자 환자를 위하여, 특별예산을 책정하여, 환자가 치료받는 기관에 지불하는 제도를 발전시켜 가 야 할것이다.

이러한 제도의 실천을 위한 준비로서 국가가 현재 할 수 있는 것은 조직체 (민간이건, 공공기관이건)에서 보 험의 가능성을 타진해 본다는것은 유익한 일일것이다.

다행이 보건사회부는 호남비료, 봉명광업소에서 1966 년부터 의료 보험시범사업을 실시한바 상당한 가능성이 보여, 의료보험법 시행령을 졔정할려고 하고 있다. 의 료보험은 전질환을 카바해야 하는 것이 상식이지만 보 사부가 추진중인 의료보험에는 결핵이 제외 되어 있다.

완전한 전체적인 의료보험은, 이상적이지만 결핵보험 은 우선적으로 중요한 질환에 대한 부분적인 보장 제도 이다.

보사부는 점진적으로 의료보험을 밭전시켜 전 국민에 게 혜택을 줄려고 도모 하고 있다. 우리나라의 현재의 경제적 여건하에서 의료보험에 참가 할 수 있는 조직체
는 소수에 국한될 것이다. 어떤 시점에서 의료보험에 가입할 수 없는 경제능력을 가진 조직체가 있다면, 단 일 질환인 결핵보험을 우선적으로 할 가능성은 없는 것 일가? 이상적인 전체적의료보험에 앞서, 결핵보험을 먼저 발전시켜가는 방법은 타당성이 있다고 생각되므로 저자는 여기에 관련된 다음의 문제들을 해명해 보기로 한다.

\section{6. 치료비문제}

\section{6-1-1. 역학적인 현실}

치료비 문제에 있어서, 역학적으로 고율의 연간 신환 발생이 있을 시는 보험료 부담이 증가될 것이라는 것은 상식적이다. 다행이도 우리나라에는 결핵실태 조사가 전 국적 규모로 2 차에 걸쳐 시행된 바 있으며, 특히 1970 , 1971년도에는 연간 발생율의 조사가 되어있어 치료비용 추산에 콘 도움이 되고 있는 것은 다행으로 생각된다.

\section{6-1-2. 일차년도 치료비}

3-18에서 언급한 바 있지만 일차년도의 근로자의 부담 은 월평균 수입 15,000 원으로 가정하였을 경우 $0.29 \%$ 이며, 기업주와 분담할 시는 $0.19 \%$ 로 금액으로는 월평 균 근로자 1 인당 약 28 원으로 결핵보험은 최소의 가능 성을 가진다. 사회적, 경제적견지에서, 근로자 1 인당 15,000 원의 수입으로서 4 명의 부대 가족을 가진 근로자 가 자신의 결핵과 가족의 결핵을 동시에 보장하는 보험 료 월 $0.19 \%$ 의 부담을 하는 것이 타당성이 있는 것인 지 아닌지에 대하여서는 더 연구가 있어야 할 것이지만 상식적으로 판단해서 가능성은 크다고 본다.

\section{6-1-3. 2차년도 치료비}

2 차년도에는 일차약 치료실패자와, 이월환자치료가 겹쳐 일차년도보다 약간 증앱된 부담을 근로자에게 부 과시킨다.

3-24에서 본바와 같이 월평균수입 15,000 원의 근로자 는 매월 봉급의 $0.24 \%$ 약 36 원를 보헐료로서 지불하여 야 한다.

\section{6-1-4. 치료비 문제의 종합적 고찰}

본연구에서의 치료비 추산은 전술한 바와 같이 서울시 내 비영리결핵전문 진료소의 수가에 의한 것이기 때문 에 의료공급자를 일반 개업의에게도 혀용할 경우에는 다시 검토되어야 할 것이다. 그러나 현재 우리의 실태 로는 평균 500 명이상의 종업원을 가진 기업체에서는 자체의 의무실이 있으며 기업체에 고용된 의사가 있으 므로 자체의 의료시설(지정 치료기관)을 활용하였을 경 우에는 월급의 $0.24 \%$ 의 부담이 사희적, 경세적 견지에 서 타당성이 있을 경우에는 기능성이 있는 것으로 판단 할 수 있을 것이다. 기타 군소 기업체도 지역적으로 연 
합하여 의료시설을 운영한다면 가능성이 있는 것으로 판단된다.

\section{6-1-5. 향후 역학적 상태의 전망과 보험}

특이한 기업체, 예컨데 방직공장등에 종사하는 독신 의 젊은 근로자에게서 발생하는 연간 신결핵환자는 극 하 소수일것으로 추산된다.

이는 결핵실태조사의 연령별 유병율로서 추측할수 있 다. 결핵은 고령에 갈수록 유병율이 높으며, 따라서 발 병율도 높으리라고 추축된다.

표 10. 년령별 $\mathrm{X}$ 선상 활동성 결핵환자 유병율

\begin{tabular}{c|c}
\hline 년 & 1970 \\
\hline 계 & 9.2 \\
$5-9$ & 2.8 \\
$10-14$ & 1.9 \\
$15-19$ & 2.5 \\
$20-24$ & 3.7 \\
$25-29$ & 2.5 \\
$30-34$ & 4.2 \\
$35-39$ & 5.4 \\
$40-44$ & 6.8 \\
$45-49$ & 6.3 \\
$50-54$ & 5.8 \\
$55-59$ & 8.8 \\
$60-64$ & 8.3 \\
$65-69$ & 11.4 \\
$70-74$ & 17.1 \\
$75-79$ & 18.0 \\
$80-84$ & 16.7 \\
\hline 5 &
\end{tabular}

1972 년 중순에는 대한결핵협회가 연령별 연간 환자 발생율도 얻어질것으로 알고 있지만 현재로서는 연령별 연간 신환 발생율은 아직 없다.

그리고 비시지 접종율로 볼때, 30 세 미만의 인구에서 는 상당이 높으며, 20 대 전후에는 $28-37 \%$ 의 접 종율을 가지고 있다. 따라서 비시지 접종자에게서는 환자 발생 은 비시지 비접종자중의 환자 발생보다 약 $80 \%$ 감소될 것으로 추산된다. 이련 여건들은 보험료 부담을 저하시 킬수 있는 요인이 될것이며 추산보혈율 $0.24 \%$ 보다 저 율을 부담할수 있는 가능성도 있다고 추리된다.
결핵 및 호홉기질환 Vol. 19, No. 1, Jan., 1972

표 11. 연령별 BCG접종율

\begin{tabular}{|c|c|}
\hline 년 & 1970 \\
\hline 계 & 30.3 \\
\hline 0 & 11.3 \\
\hline 1 & 31.2 \\
\hline 2 & 50.1 \\
\hline 3 & 49.2 \\
\hline 4 & 46.5 \\
\hline 5 & 50.4 \\
\hline 6 & 52.0 \\
\hline 7 & 48.8 \\
\hline 8 & 59.5 \\
\hline 9 & 55.4 \\
\hline 10 & 55.6 \\
\hline 11 & 52.5 \\
\hline 12 & 49.4 \\
\hline 13 & 53.5 \\
\hline 14 & 59.4 \\
\hline $15-19$ & 37.3 \\
\hline $20-24$ & 28.3 \\
\hline $25-29$ & 20.5 \\
\hline $30-34$ & 7.6 \\
\hline 35 lover & 0.4 \\
\hline
\end{tabular}

\section{6-2. 특수조직체와 보험}

중-고·대학에 제학중인 학생들에게 등록금 납입시 에 보험료를 납입한다고 가상하면, 경제적으로 별 부담 감없이 그리고 근로자의 보험율보다 상당이 저율로서 재학중의 결핵 발병에 대한 치료 보장을 할수 있는 가 능성이 크다고 추리된다. 학생만을 보장하게 되면 치료 비는 전술한 것보다 상당이 감소 될 수 있을 것이다.

\section{7. 결 론}

1) 이웃나라 일본에서는 결핵환자의 약 $98 \%$ 가 보험 의 혜택 혹은 기타의 보장제도로 생활의 위협없이 이상 적인 치료를 반고 있지만 한국에서는 국가재정의 형편 상 보건소망을 통하여 정부로부티 야간의 치료만이 보 장되어 있을뿐이고 이러한 식으로 결핵관리가 계속 된 
결핵 및 호흡기질환 Vol. 19, No. 1, Jan., 1972

다면 현대국가로서 갖춰야 할 복지사회를 이룩할 길은 너무나 요원하다고 하겠다.

그러므로 질병의 중요성을 감안해서 결핵보험을 우선 적으로 신시하는 문제를 검토해 볼 가치가 있다고 판단 된다.

2) 현재 실시되고 있는 무차별한 국가부담의 보건소 를 봉한 최저한의 결핵치료제도를 지양하고 우선 조직 체에 근무하는 근로자들이 연대적인 부담을 할수있는 결핵보험을 단계적으로 발전시켜 나가는 방법이 가능하 고 효과적이라고 생각된다.

3 ) 조직체에 근무하는 근로자의 월평균 수입을 15,000 원으로 가정하였을 경우 월 봉급의 $0.24 \%$ 씩 근로자와 기업주가 부담한다면 최소한 제일 많이 쓰이고 있는 2 차약 1321 PZ1, E. M. B. 의 3자 병합요법을 포함할수 있는 결핵보험의 가능성이 있는 것으로 추리된다.

4) 이러한 결핵보험이 실천될 때는 환자의 재량으로 의료기관을 선택하게 하는 것보다는 기업체에 기존하는 부속병원을 활용하는 것이 가장 적절한 제도로 인정된 다.

그리고 결핵은 다른병보다도 진 단기준과 치료 원칙을 따르는 것이 더욱 필요하므로 지역적인 결핵전문과의 심의제도를 두는 것이 좋다고 본다.

5) 역학적으로 젊은 근로자중에는 비시지 기접종자가 증가하고 있는 경향이며 비시지 접 종자의 증가와 기타
여건으로 연간 환자 발생율이 가속도로 감소될 수 있는 환경에 있으므로 보험료 지출의 감소가 예상되며, 또 보험료 부담도 월 $0.24 \%$ 로서 가능하다고 생각되므로 현재 정부가 계획하는 의료보험에서 결핵질환이 제외되 어 있는 것은 그렇게 타당성이 있다고 할 수 없으며, 결 핵을 의료보험에 가입시켜도 보험료 부담에는 크게 영 향을 주지 않을 것으로 전망된다.

\section{참 고 문 헌}

1) 보건사회부, 대한결핵협희 결핵연구원. 제 2 차 결핵 실태조사 결과 보고.

2) 보건소 결핵환자 치료에 관한 평가 보고. 결핵 및 호흡기질환 1969. 7월호 Vol. 16. No. 3.

3) 결핵환자 연간 발생율 조사(1970-1971) 중간보고. 대한결핵협회 결핵연구원, 1971년 제31차 결핵학술 대희

4) 의료보험장기 계획 1970. 1 보건사회부, 의정국 지 방의정 과.

5) Medical Reserch Council(1963) Brit. Med. J. 1, 973-978

6) 의료보험 관계 법령집, 보건사회부

7) The annual report of Singapore Anti-Tuberculosis Association 1968.

8) 결핵실태조사. 일본 결핵예방희 소화 35 년. 